\section{Preservation of rice strains}

SIR - K. S. Jayaraman's article, "India set to end 'gene robbery"' (Nature 370, $587 ; 1994)$ ends by saying: "India has also taken steps recently to get back some of the materials it has already lost. Two months ago, the International Rice Research Institute [IRRI] in Manila in the Philippines agreed to return to India 5,000 accessions of traditional rice strains from Assam state, which were taken away by the institute in the 1960s."

This is simply a repeat of allegations of "gene robbery" by IRRI made in an article in the Illustrated Weekly of India on 23 March 1986. One month after the article appeared, the Rice Research Workers of India were reported to have "unanimously condemned such gross distortion of facts in the article at their annual meeting in Faizabad", and in its issue of 29 June 1986 Illustrated Weekly published a four-page rebuttal of the accusations by Dr M. S. Swaminathan, then director general of IRRI

The traditional rice strains were not "taken away" by IRRI in the sense that they were removed arbitrarily or illegally. These rice strains, or germplasm, known as the Assam Rice Collection and containing more than 5,000 traditional rice cultivars, were collected 30 years ago in Assam and sent by the Indian Council of Agricultural Research for safekeeping at the IRRI genebank in Los Baños, Philippines, precisely to preserve the diversity of the rice gene pool.

"The collection included native diversity in rice available at that time in remote areas, providing valuable genes for resistance to some serious insect pests", said Dr R. S. Rana, director of India's National Bureau of Plant Genetic Resources, in a letter to IRRI, requesting that the institute duplicate the collection and send it to India because, he said, much of the original collection is no longer available because of "deterioration or loss".

The collection in IRRI's Genetic Resources Center rice genebank is a duplicate of the original Assam Rice Collection. Beginning in August, about $50 \mathrm{~kg}$ of the Assam rice seeds will be sent to India in two batches representing more than 5,000 accessions.

The IRRI rice genebank holds in trust more than 80,000 different samples of rice varieties and wild species of rice from all over the rice-growing world. Since 1973 , more than 740,000 packets of rice seeds have been distributed, free of charge, to rice scientists worldwide for use in research.

Rice seeds from many countries have contributed useful traits to modern rice varieties, such as early maturity, resistance to diseases and pests and tolerance for salinity, flooding and submergence, which have benefited mostly Asian countries.

IRRI has repatriated seeds to several countries, including the Philippines and Sri Lanka. In one case the institute helped to reintroduce to Cambodia rice seeds that had disappeared during the long civil war in that country. The lost varieties, collected in the early 1970 s in Cambodia and stored in IRRI's rice genebank, are once again being grown extensively in that country. IRRI last month repatriated to Indonesia and Thailand 416 and 392 samples respectively.

M. Jackson

Genetic Resources Center.

International Rice Research Institute,

POBox 933 ,

1099 Manila.

Philippines

\section{Combating AIDS}

SIR - Is it really true, as you say, that "the message about the dangers of AIDS is not getting through" 1 ? Numerous studies, even among disadvantaged groups ${ }^{2,3}$, show that knowledge about transmission routes is very high, but there is a hard core of people familiar to clinicians (perhaps 35 per cent of the total population at risk), who may resist counselling ${ }^{4}$ in spite of their best endeavours or fail to modify their risky behaviour ${ }^{5}$. The most successful approach so far seems to be small group therapy ${ }^{5,6}$ bearing a surprising resemblance to Alcoholics Anonymous groups.

Although the present situation may tempt us to despair, this may be historically unwise. After all, 70 years ago, the orthodox medical opinion similarly was that what we now call alcoholism was utterly incurable.

N. E. Whitehead

54 Redvers Drive,

Belmont

Lower Hutt,

New Zealand

1. Nature 371,400 (1994)

2. Stall, R. et al Med. Anthrop. Quart (New Ser.) 4, 115-128 (1990).

3. Rotheram-Borus, M. J. et al. J. Adolesc. 14, 229-244 1991)

4. Rosser. B. S. \& Ross. M. W. J. Gay Lesb. Psychother. 1 93-114 (1991)

Pincu, L.J. Couns. Dev. 68, 63-66 (1989)

6. Kelly, J. A. \& St Lawrence, J. S. AIDS Care 2, 25-35 (1990).

7. Kus, R. J.J. Homosex, 14, 253-275 (1987)

\section{Not predisposed}

SIR - Under the heading "A predisposition to astronomy" (Nature 368, 800; 1994), you say: "Astronomy in Mexico was well established when, in $650 \mathrm{AD}$ Maya, Zapotec and Theotihuacán astronomer-priests met at the hilltop observatory of Xochicalco, Morelas, to synchronize their sundials. This Mesoamerican Calendrical Convention is arguably the first scientific conference on record - the poster session is still carved into the base of the pyramid."

An examination of the base and other parts of the pyramid shows no description of a convention nor of a poster session. Nothing indicates that a calendar was synchronized in Xochicalco (Mexico) nor in Copan (Honduras), nor elsewhere in Mesoamerica.

\section{Jean-Pierre Herveg}

University of Louvain Medical School,

72 Ave E. Mounier

B1200 Brussels,

Belgium

\section{Alas, poor Yorick}

SIR - The account by Michael Fitzgerald and David Berman (Nature 368, 92; 1994) of the illness of my cousin Yorick Smythies is completely erroneous. He did not suffer from paranoid schizophrenia as they claim he did. From information I received from Yorick himself and from his wife it is clear that his original symptom was depression for which his doctor unfortunately prescribed amphetamines to which Yorick became addicted (as commonly happened) and subsequently he developed a wholly iatrogenic chronic paranoid amphetamine psychosis.

\section{J.R.Smythies}

Institute of Neurology,

Queen Square,

London WC1, UK

\footnotetext{
1. Fitzgerald, M. \& Burman, D. Nature 368, 92 (1994)

2. Churchiand, P. S. Neurophilosophy (MIT Press, Cambridge, Massachusetts, 1986).

Crick, F. The Astonishing Hypothesis (Scribner, New York,

4. Smythies, J.R. The Walls of Plato's Cave (Avebury, Aldershot 1994).
}

\section{TV's disservice to science}

SIR - I wholeheartedly agree with your criticism of the BBC's appalling 'Heretic' series, but I feel that the independent television companies do an even greater disservice to science, engineering and the enquiring mind among the young in Britain when they broadcast a series of advertisements suggesting that it is "sad" (a word the young construe somewhat differently from those over 30 ) to want to know how the "widget" in a can of beer works.

\section{Rodney W. King}

National Institute

forMedical Research,

Mill Hill,

London NW7 1AA, UK 